Acta vet. scand. $1960,1,305-323$.

From the Department of Pharmacology and Toxicology, The Royal Veterinary and Agricultural College, Copenhagen.

\title{
ELECTROLYTE EXCRETION IN THE COW, AS INFLUENCED BY VARIATIONS IN THE URINE FLOW*)
}

By

Emil Knudsen.

The electrolyte excretion in cattle has for many years been studied by means of balance tests, but cows have only within recent years been submitted to electrolyte analyses using the classical clearance technique (Sellers et al. 1958; Vogel 1959).

The objects of the present series of experiments have been to test the possibility of fixing mean values for the clearances of potassium, sodium, and chloride in cattle, and to throw some light on the effects of water loading and administration of diuretics on the electrolyte excretion. Concurrently, we have studied whether the cow might be found to possess a similar hyaluronidase mechanism regulating the urine flow as has been demonstrated by Ginetzinsky (1958) in the dog.

\section{MATERIAL AND TECHNIQUE}

As test animals we used clinically healthy, untrained, nonpregnant cows between the ages of 5 and 10 years and ranging in weight from 422 to $600 \mathrm{~kg}$. The cows were fed normally, and the electrolyte contents of the fodder were not controlled. The normal series, i.e. that given no infusions, comprised eight animals, while the series given diuretics comprised five. After the experiments the cows were sacrificed, and their kidneys as well as urinary tracts were examined both macroscopically and microscopically. In one case melanosis renis was demonstrated, but

*) Aided by grants from Godsejer Viktor A. Goldschmidts Legat and Statens almindelige Videnskabsfond. 
in the remaining cows normal conditions. The experiments were carried out on non-anaesthetised animals placed in a constriction stall. As all the cows became somewhat excited by this unusual situation, and as this seemed to influence the electrolyte excretion, exploratory experiments were conducted with calming down of the animals by means of acepromazine (Plegicil $(R))$. It appeared, however, that the cows continued to react to the experimental situation, unless brought into a state of complete torpidity, so, accordingly, this procedure was abandoned. The excitement was most often moderate, but in a few instances rather pronounced.

Blood samples were withdrawn from the right jugular vein through a permanent cannula, which was closed by a stilet between the samplings. In the experiments with diuretics the diuretic used was infused into the left jugular vein.

The urine was collected through a bulb catheter (Rüsch no. $28,75 \mathrm{ml}$ ) inflated by $100-150 \mathrm{ml}$ of air. The catheter was connected with a graduated glass by a rubber tubing, so that urine was collected continuously without stagnating in the bladder, and the urine flow could be constantly watched. At the close of each period the discharge of urine was controlled by air insufflation and moderate traction on the catheter. Using this technique, the sources of error demonstrated by Levinsky \& Berliner (1959) are likely to have become greatly reduced. These workers have shown that an appreciable diffusion of water, urea, creatinine, sodium, potassium, chloride, and hydrogen ions takes place in the ureter as well as the bladder. Especially the diffusion is considerable in cases with low urine flows and in cases where the urine remains in the bladder between the collections. Under such circumstances the difference between calyx urine and bladder urine may be up to 50 per cent.

Low urine flows are not physiological in the cow, and effective dehydration requires such prolonged thirsting that the function of the rumen becomes depressed, and the animal consequently tends towards an unphysiological state. Animals given nothing to drink for 24 hours do not all display an appreciable fall in the urine flow, as seen, for instance, in the experimental record rendered in table 1.

The periods lasted from 13 to 42 minutes, being most often about 30 minutes. All the experiments were started at 10 a.m. and concluded 2 to 5 hours later. The effects of possible 24-hours 
variations of the electrolyte metabolism (Larvor \& Brochart 1959) were then supposed to have been eliminated, so that the experiments were mutually comparable. Centrifugation of the blood samples was controlled by a stop watch and was concluded not later than 15 minutes after the sampling. The chance of equalisation between erythrocytes and plasma due to diffusion was then probably brought down to a minimum.

In calculating clearances we employed a delay time of 6 minutes (Poulsen 1956, 1957). All the clearance values measured were converted into clearance per $100 \mathrm{~kg}$ body weight. The electrolyte concentrations in urine and plasma are given in $\mathrm{mEq} / \mathrm{l}$, while the electrolyte excretion per minute is given in $\mu \mathrm{Eq}$ per 100 kg body weight.

\section{ANALYTICAL METHODS}

Endogenous creatinine: Folin's method, as modified by Thomsen (1938) and Poulsen (1956).

Both publications being available in Danish only, the procedure will be briefly stated below: As the colour of the creatine-picric acid complex depends on the time and $\mathrm{pH}$, and the precipitation of protein is performed with trichloracetic acid, the calibration curve is to be plotted using aqueous creatinine solutions, to which has been added so much less trichloracetic acid as corresponds to the loss by the protein precipitation. Hence, $8.65 \mathrm{ml}$ of $10 \%(\mathrm{w} / \mathrm{v})$ trichloracetic acid and $15.35 \mathrm{ml}$ of water are used to $6 \mathrm{ml}$ of creatine solution.

Procedure: $6 \mathrm{ml}$ of plasma, $14 \mathrm{ml}$ of water and $10 \mathrm{ml}$ of $10 \%$ $(w / v)$ trichloracetic acid were mixed and left for 30 minutes. Then followed filtration twice through the same filter (likewise the aqueous standard solution). $5 \mathrm{ml}$ of filtrate, $4 \mathrm{ml}$ of picrid acid solution $(1.18$ $\mathrm{g} / 100 \mathrm{ml}$ of $\mathrm{H}_{2} \mathrm{O}$ ) and $1 \mathrm{ml}$ of $1.6 \mathrm{n} \mathrm{NaOH}$ were mixed and left for 1 hour. Photometry was performed at $500 \mu \mu$. Reference: Reagent blank. Urine analysis: $5 \mathrm{ml}$ of urine dilution (about $2 \mu \mathrm{g}$ creatinine $/ \mathrm{ml}$ ), $4 \mathrm{ml}$ of picric acid solution and $1 \mathrm{ml}$ of $0.5 \mathrm{n} \mathrm{NaOH}$ were mixed, left for 1 hour and read on a spectrophotometer at $500 \mu \mu$. The calibration curve for urine was plotted by means of aqueous creatinine solutions instead of urine dilution.

Urea: Conway (1950). The urease used was Urease pract. grade type II Sigma.

Potassium and sodium: Flame photometry (Beckman Direct Reading Flame Photometer). In the sodium analyses we used $0.2 \%$ ammonium chloride solution as diluent, and in the potassium analyses the specimens were diluted with sodium chloride solution $(1 \mathrm{mEq} / \mathrm{l})$. 
Chloride: Schales \& Schales (1941).

Hyaluronidase: Dalgaard-Mikkelsen \& Kvorning (1948). Hyaluronic acid prepared from bovine synovial fluid, as indicated by these authors, was used as well as freeze-dried hyaluronic acid ${ }^{*}$ ). In control specimens hyaluronidase Penetrase Leo $(\mathbf{R}){ }^{*}$ ) was used. The viscosimeters were provided with bulbs of $0.1 \mathrm{ml}$ and had flow times for water of about 40 seconds.

\section{RESULTS REGARDING THE NORMAL MATERIAL AND WATER LOADING EXPERIMENTS \\ Hyaluronidase.}

Christensen (1938) was the first to note the presence of a spreading factor in human urine.

Ginetzinsky et al. (1954) identified this factor with hyaluronidase and demonstrated its presence in urine from man and dog at low urine flows. Similar experiments have recently been carried on by Knudsen (1959) on human subjects. The results of the continued investigations by the Ginetzinsky school (Ivanova 1958; Ginetzinsky \& Ivanova 1958; Ginetzinsky, Sax \& Titova 1958; Ginetzinsky 1958) gave rise to the hypothesis that the antidiuretic hormone effects secretion of hyaluronidase in the cells of the collecting tubules. Hyaluronidase depolymerises the intracellular cement, thus allowing water from the lumen of the collecting tubules to be reabsorbed. At the same time part of the hyaluronidase is excreted into the urine. At high urine flow the distal part of the nephron is impermeable to water (see, for instance, Smith 1959). Ginetzinsky's school explains this in the way that the hyaluronidase secretion ceases when the antidiuretic hormone disappears from the circulation. Since the publication of Berlyne's work (1960) Ginetzinsky's hypothesis seems, however, to have been entirely refuted.

In the experimental series under review hyaluronidase was found in no urine specimen from cow.

As stated above, low urine flows (i. e. about $1 \mathrm{ml} / \mathrm{min}$.) are unphysiological in the cow and difficult to obtain. The smallest urine volumes in the present series were about $3 \mathrm{ml} / \mathrm{min}$. As, however, at the same time the percentage excreted of urea was about $20(19-24)$, a rather pronounced antidiuresis must be

*) Kindly placed at our disposal by Leo Pharmaceuticals, Ltd., Copenhagen. 
supposed to have been present in these cases. In the normal series the urine volumes ranged from 2.8 to $52.2 \mathrm{ml} / \mathrm{min}$. In a few instances there were found signs of an insignificant antihyaluronidase action in the urine. As a further control, some of the urine specimens were kindly examined for hyaluronidase and antihyaluronidase at the Central Laboratory, the Municipal Hospital of Copenhagen. The results agreed with those published here.

\section{Endogenous Creatinine and Urea.}

Baldwin et al. (1949) have shown that even small infusions of $0.9 \% \mathrm{NaCl}$ influence the renal plasma flow, the filtration rate, as well as the electrolyte excretion. In the present investigation the endogenous creatinine clearance was therefore employed throughout as a measure of the filtration, because as Poulsen (1956) has shown creatinine and inulin clearances in cows are approximately equal, and, unlike the inulin clearance, determination of creatinine clearance does not necessitate infusion of a test solution, being therefore unable to influence the simultaneously measured electrolyte clearances. The urea clearance has the same advantage, and, in addition, it affords a possibility of evaluating a possible antidiuresis.

In the material (comprising 15 experiments on eight cows, a total of 55 observations) the creatinine clearance per $100 \mathrm{~kg}$ body weight was $154 \pm 27 \mathrm{ml} / \mathrm{min}$., and the urea clearance per $100 \mathrm{~kg}$ body weight, at urine flows above the augmentation limit (21 observations), $77 \pm 11 \mathrm{ml} / \mathrm{min}$., i.e. 9 and 4 per cent lower respectively than in Poulsen's material $(1956,1957)$.

On measuring the urea clearance we noticed in several cases the "exaltation phenomenon" (Shannon 1936) during the period with the steepest rise of the urine flow. This phenomenon was due to the percentage of urea excreted having risen to $64-87$ within the period concerned.

\section{Potassium, Sodium, and Chloride.}

Regarding the electrolytes, similar conditions were found as in experiments on dogs (Ali et al. 1959), namely that excitation and water diuresis resulted in falling clearance values, and that there was no correlation between the urine volume and the excretion of electrolytes. Seller \& Roepke (1951 a) were the first to observe this failing correlation in a cow.

The experimental procedure and several of the observations 
Table 1 .

Cow no. 1-El. Weight $560 \mathrm{~kg}$. Kidney weight $1420 \mathrm{~g}$.

24 hours of water deprivation before 1. period.

501 water perorally between 2 . and 3 . period.

25 l water perorally during 4 . period.

\begin{tabular}{|c|c|c|c|c|c|c|c|c|c|c|}
\hline & \multirow[t]{2}{*}{$\begin{array}{c}\text { Pe- } \\
\text { riod } \\
\text { no. }\end{array}$} & \multirow[t]{2}{*}{ Min. } & \multirow[t]{2}{*}{$\begin{array}{l}\text { Urine } \\
\text { flow } \\
\mathrm{ml} / \mathrm{min} \text {. }\end{array}$} & \multirow[t]{2}{*}{$\begin{array}{c}\text { Urine } \\
\mathrm{pH}\end{array}$} & \multicolumn{2}{|c|}{$\begin{array}{l}\text { Concen- } \\
\text { tration } \\
\mu \mathrm{g} / \mathrm{ml}\end{array}$} & \multirow{2}{*}{$\begin{array}{c}\text { Clea- } \\
\text { rance } \\
\mathrm{ml} / \mathrm{min} \text {. } \\
\text { per } \\
100 \mathrm{~kg} \\
\text { body wt. }\end{array}$} & \multirow{2}{*}{$\begin{array}{l}\text { Ex- } \\
\text { cretion } \\
0 \%\end{array}$} & \multirow[t]{2}{*}{$\mathbf{U} / \mathbf{P}$} & \multirow[t]{2}{*}{$\begin{array}{c}\mu \mathrm{Eq} / \\
\min . \text { per } \\
100 \mathrm{~kg}\end{array}$} \\
\hline & & & & & Urine & Plasma & & & & \\
\hline \multirow[t]{8}{*}{ Creatinine } & 1 & 29 & 18.6 & 8.3 & 768 & 16.0 & 159 & & 48.0 & \\
\hline & 2 & 23 & 13.8 & 8.5 & 920 & 15.3 & 148 & & 60.1 & \\
\hline & 3 & 27 & 12.9 & 8.5 & 1024 & 14.7 & 161 & & 69.7 & \\
\hline & 4 & 27 & 16.3 & 8.5 & 770 & 14.5 & 155 & & 53.1 & \\
\hline & 5 & 23 & 16.2 & 8.5 & 804 & 14.5 & 160 & & 55.5 & \\
\hline & 6 & 33 & 20.3 & 8.3 & 652 & 14.2 & 166 & & 45.9 & \\
\hline & 7 & 41 & 52.2 & 8.0 & 240 & 14.8 & 151 & & 16.2 & \\
\hline & & & & \multicolumn{7}{|c|}{ Mean $157 \pm 6$} \\
\hline \multirow[t]{8}{*}{ Urea } & 1 & & & & 7825 & 322 & 81 & 51 & 24.3 & \\
\hline & 2 & & & & 9875 & 325 & 75 & 51 & 30.4 & \\
\hline & 3 & & & & 10675 & 325 & 76 & 47 & 32.8 & \\
\hline & 4 & & & & 9925 & 330 & 88 & 57 & 31.1 & \\
\hline & 5 & & & & 10100 & 309 & 95 & 59 & 32.7 & \\
\hline & 6 & & & & 8225 & 308 & 97 & 58 & 26.7 & \\
\hline & 7 & & & & 2761 & 310 & 83 & 55 & 8.9 & \\
\hline & & & & \multicolumn{7}{|c|}{ Mean $85 \pm 9$} \\
\hline \multirow{8}{*}{ Potassium } & & & & & $\mathrm{mEq} / \mathrm{l}$ & $\mathrm{mEq} / \mathbf{l}$ & & & & \\
\hline & 1 & & & & 206 & 4.5 & 152 & 95 & 45.8 & 684 \\
\hline & 2 & & & & 225 & 4.4 & 126 & 85 & 51.1 & 555 \\
\hline & 3 & & & & 232 & 4.1 & 130 & 81 & 56.6 & 535 \\
\hline & 4 & & & & 150 & 3.5 & 125 & 81 & 42.9 & 437 \\
\hline & 5 & & & & 150 & 4.2 & 103 & 64 & 35.7 & 434 \\
\hline & 6 & & & & 75 & 3.5 & 78 & 47 & 21.4 & 272 \\
\hline & 7 & & & & 20 & 3.2 & 58 & 39 & 6.3 & 186 \\
\hline \multirow[t]{7}{*}{ Sodium } & 1 & & & & 152 & 146 & 3.5 & 2.2 & 1.0 & 505 \\
\hline & 2 & & & & 134 & 147 & 2.3 & 1.5 & 0.9 & 330 \\
\hline & 3 & & & & 128 & 142 & 2.1 & 1.3 & 0.9 & 295 \\
\hline & 4 & & & & 163 & 138 & 3.4 & 2.2 & 1.2 & 474 \\
\hline & 5 & & & & 165 & 135 & 3.5 & 2.2 & 1.2 & 477 \\
\hline & 6 & & & & 84 & 131 & 2.3 & 1.4 & 0.6 & 305 \\
\hline & 7 & & & & 21 & 131 & 1.5 & 1.0 & 0.2 & 196 \\
\hline \multirow[t]{7}{*}{ Chloride } & 1 & & & & 120 & 102 & 3.9 & 2.5 & 1.2 & 399 \\
\hline & 2 & & & & 95 & 102 & 2.3 & 1.6 & 0.9 & 234 \\
\hline & 3 & & & & 74 & 102 & 1.7 & 1.1 & 0.7 & 170 \\
\hline & 4 & & & & 33 & 100 & 1.0 & 0.6 & 0.3 & 96 \\
\hline & 5 & & & & 25 & 100 & 0.7 & 0.5 & 0.3 & 72 \\
\hline & 6 & & & & 18 & 99 & 0.7 & 0.4 & 0.2 & 65 \\
\hline & 7 & & & & 6 & 99 & 0.6 & 0.4 & 0.1 & 56 \\
\hline
\end{tabular}


are illustrated by the complete experimental record rendered in table 1 and originating from one of the least excited cows of the series.

The table shows that the $\mathrm{pH}$ of the urine fell with increasing urine flow, a fact which was noticed in nearly all the experiments. In experiments without water loading and at a fairly constant urine flow the $\mathrm{pH}$ of the urine, which always exceeds 7 in the cow, also tended to fall $0.1-0.3$ units during the experimental period, as a rule 0.2 . This phenomenon is not expressed in table 1; but in Poulsen's material (1956) the $\mathrm{pH}$ of the urine is given in 56 experimental records, in two of which with artificial shift of the $\mathrm{pH}$. In 36 of the remaining 54 records the $\mathrm{pH}$ is stated to have fallen during the experiment, while in five experiments it started with a rise, and then fell to below the starting value.

In all the present experiments we found, as stated, greatly falling clearance values for the three electrolytes, as also seen in the record rendered above. On this account no statistical treatment of the material of figures was attempted. However, if we regard he first period of each experiment as representing the state coming the nearest to the physiological, the experimental series seems to show that the potassium clearance in the cow averaged about $110 \mathrm{ml} / \mathrm{min}$. per $100 \mathrm{~kg}$ body weight $(50-179$ $\mathrm{ml} / \mathrm{min}$.). It was, in other words, of the same order as the filtration clearance (Vogel 1959), the percentage excreted being about $75(60-98)$. In this connection we must bear in mind that the fodder was rich in potassium. The potassium excretion per $100 \mathrm{~kg}$ body weight averaged about $400 \mu \mathrm{Eq} / \mathrm{min}$. (309-697). In the course of each experiment the excretion fell by from 10 to 15 per cent. The percentage amounts excreted never exceeded 100 (Vogel 1959) in the normal material.

The plasma level of potassium, calculated from the first blood sample withdrawn in each experiment (15 observations), averaged $4.0 \pm 0.3 \mathrm{mEq} / \mathrm{l}(3.6-4.5)$. For all 55 observations the average was $3.9 \pm 0.3 \mathrm{mEq} / \mathrm{l}(3.2-4.5)$, in agreement with $\mathrm{Sel}$ lers \& Roepke's values (1951 b), but somewhat lower than those of Bergman \& Sellers (1953, 1954) and McSherry \& Grinyer (1954).

The plasma level of potassium fluctuated surprisingly much in the individual experiment. In table 1 this fact is probably further accentuated by the two-stage water loading, but even in experiments without water loading and a rather constant urine 
flow irregular fluctuations between 4.2 and $3.6 \mathrm{mEq} / \mathrm{l}$ were the rule. No acceptable explanation could be given of this inconvenient finding. Its cause is, perhaps, to be sought in the intracellular environment (Wilson 1948), possibly in a neurohumoral action on the membrane potential of the erythrocytes (Greig \& Gibbons 1956). The cow is, it is true, one of the mammals whose erythrocytes contain considerably more sodium than potassium (Bernstein 1954; Smith 1956). The difference is, however, quantitative more than qualitative, the potassium concentration in the erythrocytes being even in the cow six or seven times higher and that of sodium about 50 per cent lower than the plasma levels of potassium and sodium.

It is seen in table 1 that the sodium clearance fell during the first three periods and rose to the starting value within the fourth period, then to fall abruptly again. This was interpreted as a result of the water load (13 per cent of the body weight), of which $25 \mathrm{I}$ were given within the fourth period. The most frequent observation was a fairly steadily falling sodium clearance, both at constant and at varying urine flows. The results from all the first periods were that the percentage of sodium excreted averaged about $1.5(0.2-3.7)$, while the clearance per $100 \mathrm{~kg}$ body weight averaged about $2 \mathrm{ml} / \mathrm{min}$. $(0.3-6.6)$ and the excretion per $100 \mathrm{~kg}$ body weight about $300 \mu \mathrm{Eq} / \mathrm{min}$. (39-950).

In the example instanced above the plasma level of sodium fell, a fact which likewise was interpreted as a result of the heavy water load, this value having varied but little in the total material during the experiments. The value was $140 \pm 4 \mathrm{mEq} / \mathrm{l}$ (134146) in the fifteen first periods and $139 \pm 4$ in all 55 observations (134-146 mEq/1). Sellers \& Roepke (1951 b), Bergman \& Sellers (1953), and McSherry \& Grinyer (1954) set this value at 142-$145 \mathrm{mEq} / \mathrm{l}$.

Kattus et al. (1948, 1949) studied the influence of muscular work on the filtration clearance and sodium excretion in man. They found mild muscular work to cause retention of sodium without influencing the filtration, whereas hard muscular work reduced the sodium excretion as well as the filtration rate. If we regard the excitement of the cows as mild muscular work, our observations agree with those of Kattus et al. In cow no. 2 the excitement corresponded definitely to hard muscular work. Its filtration rate per $100 \mathrm{~kg}$ body weight fell from 190 to 108 $\mathrm{ml} / \mathrm{min}$., to rise again within the last period to $125 \mathrm{ml} / \mathrm{min}$., while 
the sodium clearance per $100 \mathrm{~kg}$ body weight fell from 0.6 to 0.1 $\mathrm{ml} / \mathrm{min}$. Calculated in $\mu \mathrm{Eq} / \mathrm{min}$. per $100 \mathrm{~kg}$ body weight, the sodium excretion fell from 90 to 18 , while that of chloride fell only from 100 to 69 and that of potassium from 687 to $361 \mu \mathrm{Eq} / \mathrm{min}$. per $100 \mathrm{~kg}$ body weight.

The excretion of chloride followed very closely that of sodium in the total material, the percentage excreted averaging about 0.8 $(0.2-2.5)$. The clearance per $100 \mathrm{~kg}$ body weight averaged about $1.0 \mathrm{ml} / \mathrm{min}$. $(0.2-3.9)$ and the excretion per $100 \mathrm{~kg}$ body weight about $110 \mu \mathrm{Eq} / \mathrm{min}$. $(23-399)$, estimated on the basis of the first periods.

The plasma level of chloride was likewise found to be very constant during the experiments. The value for the fifteen first periods was $101 \pm 4 \mathrm{mEq} / \mathrm{l}(95-109)$ and for all 55 observations $102 \pm 4 \mathrm{mEq} / \mathrm{l}(95-109)$. Sellers \& Roepke (1951 b) found this value to be $102-109$, and McSherry \& Grinyer (1954) about 103.

\section{RESULTS OF THE EXPERIMENTS WITH DIURETICS}

To illustrate how the electrolyte excretion of the cow is influenced by diuresis brought about by diuretics eight experiments were carried through on five cows, with altogether 47 observations. The diureses ranged from 3.1 to $53.0 \mathrm{ml} / \mathrm{min}$. As the modern diuretics have been made use of in the treatment of oedema of the cow's udder, among others (Gouge 1959; Flückiger \& Hofer 1960), chlorthiazide was used for these experiments. Further, one week after the chlorthiazide experiments, parallel experiments with mersalyl (without theophylline) were carried out on each cow, for the sake of comparison, although mecurials are avoided, as far as possible, in the clinical treatment of cows.

The doses chosen per cow were $4.5 \mathrm{~g}$ chlorthiazide and, in the parallel experiments, $2.5 \mathrm{~g}$ mersalyl, both in $300 \mathrm{ml}$ of water given by intravenous infusion. In two supplementary experiments the effect of a minimum dose of chlorthiazide $(150 \mathrm{mg}$ per cow) was studied. The test animals had been fed and watered normally previous to the experiment. The results therefore reflect the response of the physiologically normal cow to diuretics.

\section{Chlorthiazide.}

The results of the experiment illustrated in fig. 1 represent the conditions found without exception in all the chlorthiazide experiments using a large dose $(4.5 \mathrm{~g})$. It is seen that chlorthia- 

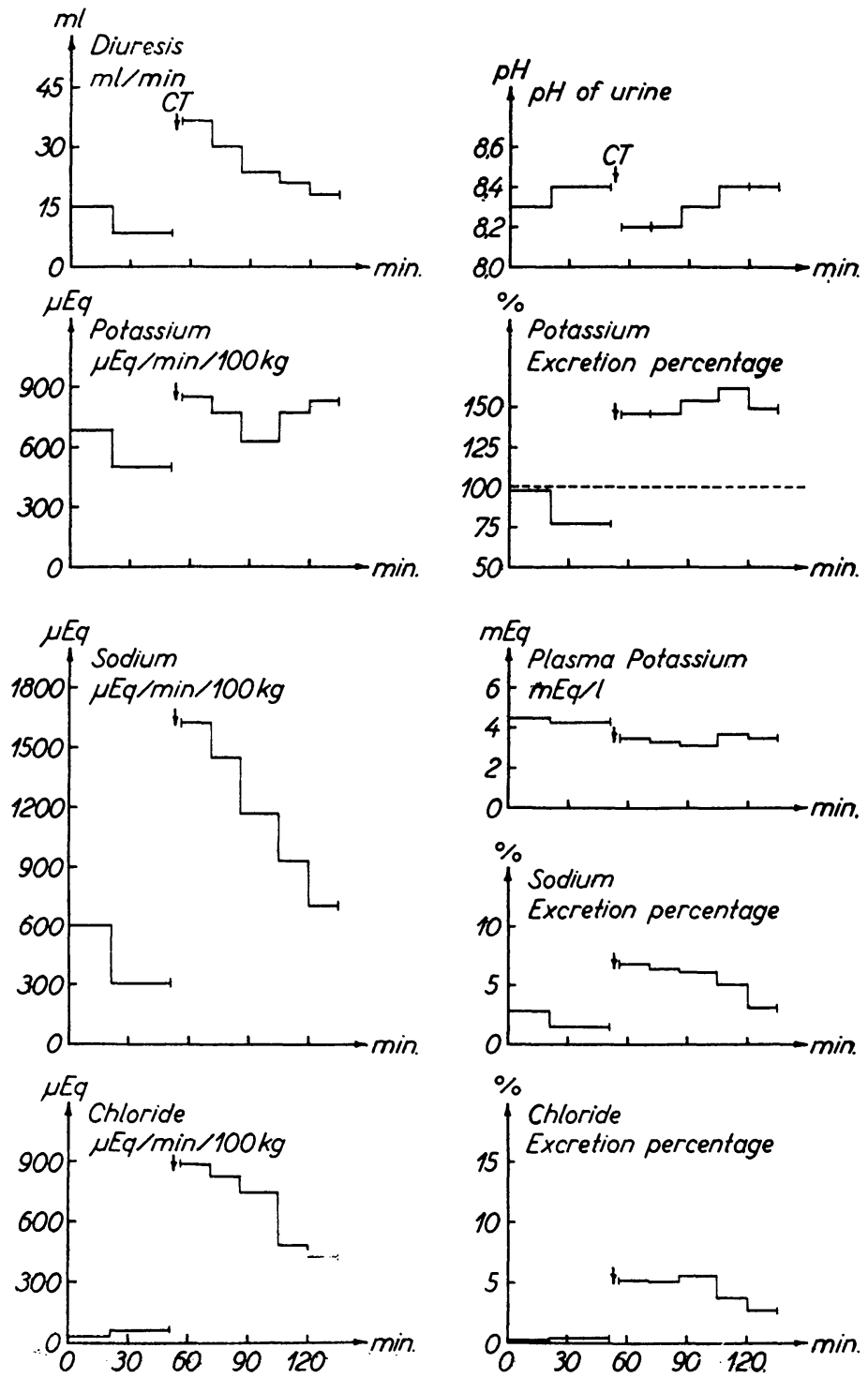

Fi g. 1. Cow no. 5-El-D. $435 \mathrm{~kg}$ body weight. $4.5 \mathrm{~g}$ chlorthiazide i.v. between 2 . and 3 . period.

zide effected a momentary moderate increase of the urine flow, which soon fell again to the starting level. The $\mathrm{pH}$ curve shows, as stated previously, that the urine flow and the pH usually vary inversely. That the $\mathrm{pH}$ fell immediately after the administration 
of chlorthiazide must be ascribed to this mechanism in connetion with the fact that the cow's urine normally is alkaline. The phenomenon also manifested itself at normal water diuresis and mersalyl diuresis.

Fig. 1 shows, further, that the potassium excreted per minute rose moderately (Baer et al. 1959). More interesting is, however, the fact that the percentage excreted of potassium exceeded 100 in all the chlorthiazide experiments. This was partially due to the actual potassium excretion per minute, but was also, and to a greater extent, attributable to the fall in the plasma potassium level always seen following chlorthiazide infusion. The plasma values are given below the column indicating the percentage of potassium excreted.

For sodium and chloride a pronounced rise is seen of the excretion per minute as well as of the percentage excreted. The rise follows fairly closely the course of the diuresis curve.

$A$ fall in the filtration clearance was demonstrated in none of the chlorthiazide experiments. Blackmore (1959), in experiments on dogs given permanent chlorthiazide infusion, found a fall of the glomerular filtration rate of about 20 per cent, which he explained by the altered water and electrolyte absorption in the tubules.

In two supplementary experiments $150 \mathrm{mg}$ chlorthiazide were infused each time into a cow. This gave a weak, though distinct increase of the urine flow, which likewise fell rapidly again, whereas the $\mathrm{pH}$ of the urine behaved conversely. The potassium excretion did not rise, but the percentage of potassium excreted rose momentarily from about 60 to about 80 , then to fall parallel with the diuresis. The rise of the percentage excreted was also here due to a fall of the plasma potassium level. The excretions of sodium and chloride rose five- to ten-fold, and fell again immediately after, likewise parallel with the diuresis. The same was reflected in the percentages excreted of sodium and chloride.

In all the chlorthiazide experiments the plasma levels of sodium and chloride remained constant.

The observations therefore justify the conclusion that in the cow, too, the point of attack of chlorthiazide is the tubular regulation of the sodium and chloride excretion (Beyer et al. 1957, Ford et al. 1957). No explanation has been attempted of the apparantly inevitable fall of the plasma potassium level. Baer et al. (1959), who have shown that chlorthiazide is excreted in the 

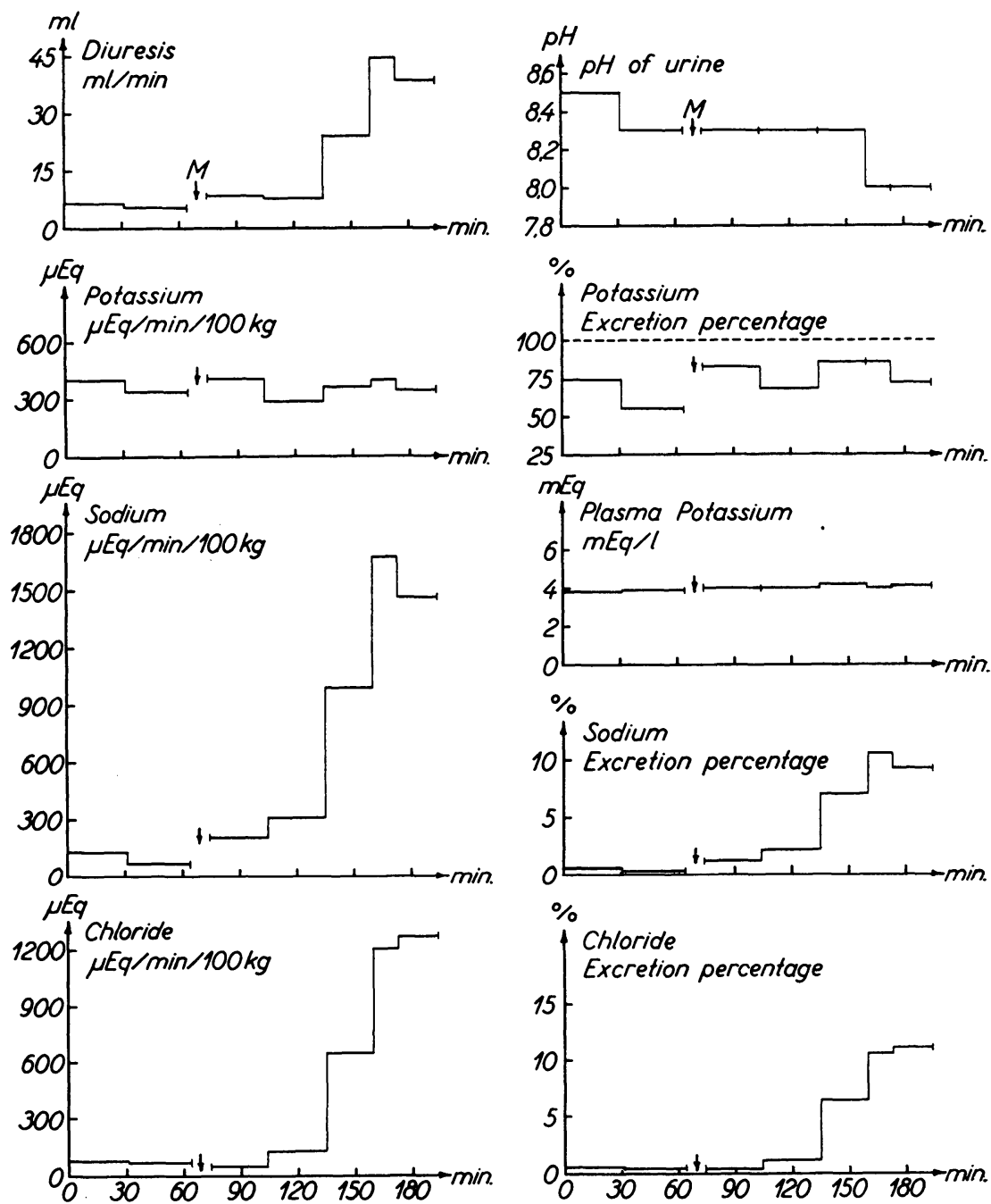

F i g. 2. Cow no. 5-El-D. $435 \mathrm{~kg}$ body weight.

$2.5 \mathrm{~g}$ mersalyl i.v. between 2 . and 3 . period.

tubules, probably by the same mechanism as para-amino hippuric acid, penicillin, and other acids, have demonstrated, by means of $\mathrm{C}^{14}$-labelled chlorthiazide, that the drug does not accumulate in the erythrocytes. A possible explanation is that chlorthiazide acts on the $\mathrm{pH}$ regulation in the cell membrane. That the drug at any rate acts on cell membranes outside the kidney was evident from the fact that all the cows developed a moderate cough 
shortly after the administration of chlorthiazide. This was interpreted as a sign of an increased secretion in the bronchi.

\section{Mersalyl.}

Fig. 2 presents the mersalyl experiment parallel to the chlorthiazide experiment shown in fig. 1. Fig. 2 illustrates how the urine flow rose slowly after administration of mersalyl, but reached a higher level, where it remained for a longer period. The pH changes corresponded to those stated above.

Furthermore, it is seen that neither the potassium excretion nor the plasma potassium level altered in response to mersalyl, in contrast to the conditions after infusion of chlorthiazide. Sodium and chloride, on the other hand, behaved in the same way as in the chlorthiazide experiments: The excretion of these two electrolytes rose appreciably, and the rise proceeded approximately parallel to the increasing diuresis.

The material under review might therefore suggest that the diureses following administration of chlorthiazide and of mersalyl are primarily provoked by the same mechanism. However, this conclusion is, of course, unjustifiable on the basis of the rough methods of investigation employed here and is definitely contradicted by the results of histochemical analyses. Thus, the works of Hess (1959) and Bickers et al. (1960) revealed topographic differences between the actions on the tubules produced by the two drugs, and Pitts et al.'s work (1958) showed that the maximum effect of a mercurial diuretic can be intensified by subsequent administration of chlorthiazide. The latter authors concluded from this observation that the sodium and chloride excretions are controlled either by three functionally different mechanisms or by a single mechanism provided with energy from three different sources, of which chlorthiazide acts on one and mercurial diuretics on another, while the third is subject to no influence. Using the disputed stop flow technique, on the other hand, it has only been possible to demonstrate a marked difference between chlorthiazide and mercurial diuretics with regard to their actions on the potassium excretion (Vander et al. $1958,1959)$, this remaining uninfluenced by the mercurials, whereas chlorthiazide seemed to raise the distal tubular potassium secretion.

Unintentionally the present series of experiments with mersalyl confirmed the old experience of the clinicians that mercurials 
Table 2.

Cow no. 7-El-D. Weight $451 \mathrm{~kg}$.

$2.5 \mathrm{~g}$ mersalyl intravenously after 3 . period.

30 min. pause before 4 . period.

\begin{tabular}{|c|c|c|c|c|c|c|c|c|c|c|}
\hline & \multirow[t]{2}{*}{$\begin{array}{l}\text { Pe- } \\
\text { riod } \\
\text { no. }\end{array}$} & \multirow[t]{2}{*}{ Min. } & \multirow[t]{2}{*}{$\begin{array}{l}\text { Urine } \\
\text { flow } \\
\mathrm{ml} / \mathrm{min} \text {. }\end{array}$} & \multirow[t]{2}{*}{$\begin{array}{c}\text { Urine } \\
\text { pH }\end{array}$} & \multicolumn{2}{|c|}{$\begin{array}{c}\text { Concen- } \\
\text { tration } \\
\mu \mathrm{g} / \mathrm{ml}\end{array}$} & \multirow{2}{*}{$\begin{array}{c}\text { Clea- } \\
\text { rance c } \\
\mathrm{ml} / \mathrm{min} . \\
\text { per } \\
100 \mathrm{~kg} \\
\text { body wt. }\end{array}$} & \multirow{2}{*}{$\begin{array}{l}\text { Ex- } \\
\text { cretion } \\
0 \% \\
\\
\end{array}$} & \multirow[t]{2}{*}{$\mathbf{U} / \mathbf{P}$} & \multirow[t]{2}{*}{$\begin{array}{c}\mu \mathrm{Eq} / \\
\text { min. per } \\
100 \mathrm{~kg}\end{array}$} \\
\hline & & & & & Urine & Plasma & & & & \\
\hline \multirow[t]{8}{*}{ Creatinine } & 1 & 35 & 8.3 & 8.7 & 970 & 14.3 & 125 & & 67.8 & \\
\hline & 2 & 31 & 3.7 & 8.7 & 1925 & 13.5 & 117 & & 142.6 & \\
\hline & 3 & 36 & 3.6 & 8.6 & 2675 & 13.5 & 158 & & 198.1 & \\
\hline & 4 & 30 & 11.0 & 8.5 & 536 & 14.9 & 88 & & 36.0 & \\
\hline & 5 & 31 & 13.9 & 8.4 & 342 & 15.5 & 68 & & 22.1 & \\
\hline & 6 & 25 & 21.0 & 8.2 & 220 & 16.1 & 64 & & 13.7 & \\
\hline & 7 & 26 & 34.2 & 8.2 & 136 & 16.9 & 61 & & 8.1 & \\
\hline & 8 & 25 & 32.8 & 8.1 & 138 & 17.3 & 58 & & 8.0 & \\
\hline \multirow[t]{9}{*}{ Urea } & 1 & & & & 6083 & 183 & 61 & 49 & 33.2 & \\
\hline & 2 & & & & 11340 & 182 & 51 & 44 & 62.3 & \\
\hline & 3 & & & & 16670 & 177 & 75 & 48 & 94.2 & \\
\hline & 4 & & & & 4338 & 174 & 61 & 69 & 24.9 & \\
\hline & 5 & & & & 2478 & 174 & 44 & 65 & 14.2 & \\
\hline & 6 & & & & 1457 & 172 & 39 & 62 & 8.5 & \\
\hline & 7 & & & & 969 & 172 & 43 & 70 & 5.6 & \\
\hline & 8 & & & & 954 & 173 & 40 & 69 & 5.5 & \\
\hline & & & & & $\mathrm{mEq} / \mathrm{l}$ & $\mathrm{mEq} / 1$ & & & & \\
\hline \multirow[t]{8}{*}{ Potassium } & 1 & & & & 168 & 4.1 & 75 & 60 & 41.0 & 309.2 \\
\hline & 2 & & & & 260 & 4.0 & 53 & 46 & 65.0 & 213.3 \\
\hline & 3 & & & & 264 & 3.8 & 56 & 35 & 69.5 & 210.7 \\
\hline & 4 & & & & 76 & 3.4 & 55 & 62 & 22.4 & 185.4 \\
\hline & 5 & & & & 53 & 3.3 & 50 & 73 & 16.1 & 163.3 \\
\hline & 6 & & & & 37 & 3.4 & 51 & 80 & 10.9 & 172.3 \\
\hline & 7 & & & & 27 & 3.5 & 59 & 96 & 7.7 & 204.7 \\
\hline & 8 & & & & 33 & 3.5 & 69 & 118 & 9.4 & 240.0 \\
\hline \multirow[t]{8}{*}{ Sodium } & 1 & & & & 218 & 137 & 2.9 & 2.3 & 1.6 & $\overline{401.2}$ \\
\hline & 2 & & & & 206 & 137 & 1.2 & 1.1 & 1.5 & 169.0 \\
\hline & 3 & & & & 160 & 138 & 0.9 & 0.6 & 1.2 & 127.7 \\
\hline & 4 & & & & 222 & 137 & 4.0 & 4.5 & 1.6 & 541.5 \\
\hline & 5 & & & & 219 & 137 & 4.9 & 7.2 & 1.6 & 675.0 \\
\hline & 6 & & & & 178 & 137 & 6.1 & 9.5 & 1.3 & 828.8 \\
\hline & 7 & & & & 178 & 138 & 9.8 & 16.0 & 1.3 & 1349.8 \\
\hline & 8 & & & & 194 & 137 & 10.3 & 17.7 & 1.4 & 1410.9 \\
\hline \multirow[t]{8}{*}{ Chloride } & 1 & & & & 18 & 102 & 0.3 & 0.3 & 0.2 & 33.1 \\
\hline & 2 & & & & 25 & 103 & 0.2 & 0.2 & 0.2 & 20.5 \\
\hline & 3 & & & & 26 & 105 & 0.2 & 0.1 & 0.2 & 20.8 \\
\hline & 4 & & & & 29 & 105 & 0.7 & 0.8 & 0.3 & 70.7 \\
\hline & 5 & & & & 74 & 105 & 2.2 & 3.2 & 0.7 & 228.1 \\
\hline & 6 & & & & 106 & 102 & 4.8 & 7.6 & 1.0 & 493.6 \\
\hline & 7 & & & & 110 & 103 & 8.1 & 13.3 & 1.1 & 834.1 \\
\hline & 8 & & & & 118 & 101 & 8.5 & 14.6 & 1.2 & 858.2 \\
\hline
\end{tabular}


should not be used for cows, two cows having developed acute nephrosis after the infusion of mersalyl. Although these cows are not included in the material, the complete experimental record of one will be rendered below, because clearance determinations at the initial stage of a nephrosis probably are rare.

A striking feature of these two mersalyl nephroses was an instantaneous decrease of the filtration clearance, as is plain to see in table 2. This decrease, together with the fall of the plasma potassium level, was the cause of the rise in the percentage of potassium excreted, within the last period even to over 100 , although the actual potassium excretion remained unchanged. Moreover, it is noted that the plasma creatinine level rose steadily after the poisoning, whereas the urea level remained unchanged (concentrates were fed neither before nor after the experiment). The day after the experiment the plasma creatinine level was $39.0 \mu \mathrm{g} / \mathrm{ml}$ and plasma urea $970.0 \mu \mathrm{g} / \mathrm{ml}$. The urine continued to be discoloured. 6 days later the two plasma levels were $27.0 \mu \mathrm{g} / \mathrm{ml}$ and $600.0 \mu \mathrm{g} / \mathrm{ml}$, and the cow was dismissed as cured after 3 weeks. The other mersalyl-poisoned cow displayed no clinical signs of illness after the conclusion of the experiment, and the discoloration of the urine subsided after few hours. The cow was sacrificed, and microscopy of the kidneys revealed vacuolar and hyaline degeneration in the proximal tubules.

\section{CONCLUSION}

The normal series showed that it was a mental stress on a cow to be used in clearance experiments, even with the gentle technique employed here. The excitement might result in more or less muscular work during the experiment. While this circumstance does not preclude attainment of a useful material of figures for a great number of substances (Poulsen 1956, 1957), it seemed, according to the results of the present experiments, to greatly affect the electrolyte clearances.

A common feature seemed to be that of a slightly falling urine flow and urine $\mathrm{pH}$, as well as greatly falling electrolyte clearances, supposed to be a result of $\mathrm{ADH}$ and aldesterone actions. Therefore, even the figures from the first periods must be accepted with some reservation. The literature available presents comparable figures only where the potassium clearance is concerned, which showed fair agreement with that stated by Sellers 
et al. (1958) ( $45-88 \mathrm{ml} / \mathrm{min}$. per square metre of body surface), measured in cows immediately before calving.

The experiments conducted with diuretics seemed to show that chlorthiazide as well as mersalyl act by the same mechanisms in cows as in other animal species. The instability of the plasma potassium level in the normal series and its susceptibility to chlorthiazide call for further investigation.

In the rare instances where clinical treatment with a diuretic is required to a cow chlorthiazide seems, according to this experimental series, to be an effective and safe drug. The results of the mersalyl experiments confirmed that mercurials are dangerous to cows. The primary effect of the poisoning seemed to be a considerable fall of the filtration clearance.

\section{Acknowledgements}

The author wishes to express his best thanks to Docent, Dr. E. Poulsen for his help and interest in this work.

\section{REFERENCES}

Ali, M. N., R. B. Cross \& M. Pickford: J. Physiol. 1958, 141, 177.

Baer, J. E., H. L. Leidy, A. V. Brooks \& K. H. Beyer: J. Pharmacol. \& Exper. Therap. 1959, 125, 295.

Baldwin, D., E. M. Kahana \& R. W. Clarke: Med. Dept. Field. Res. Lab., Fort Knox, Ky. 1949, Project no 6-64-12-06-(17).

Bergman, E. N. \& A. F. Sellers: Amer. J. Vet. Res. 1953, 14, 520.

Bergman, E. N.\& A. F. Sellers: Amer. J. Vet. Res. 1954, 15, 25.

Berlyne, G. M.: Nature 1960, 185, 389.

Bernstein, R. E.: Science 1954, 120, 459.

Beyer, K. H., J. E. Baer, H. F. Russo \& A. S.Haimbach: Fed. Proc. 1957,16, 282.

Bickers, J. H., E. H. Bresler \& R. Weinberger: J. Pharmacol. \& Exper. Therap. 1960, 128, 283.

Blackmore, W. P.: J. Pharmacol. \& Exper. Therap. 1959, 125, 303.

Christensen, J. F.: Hospitalstidende 1938, 81, 572.

Conway, E. J.: Microdiffusion Analysis and Volumetric Error, 3rd ed., London 1950.

Dalgaard-Mikkelsen, S. \& S. A. Kvorning: Acta pharmacol. et toxicol. 1948, 4, 169.

Flückiger, U.\& A. Hofer: Schweiz. Arch. Tierheilk. 1960, 102, 27.

Folin, O.: Ztschr. physiol. Chem. 1904, 41, 223.

Ford, R. V., J. H. Moyer \& C. L. Spurr: Arch. intern. Med. 1957, 100, 582.

Ginetzinsky, A. G.: Nature 1958, $182,1218$.

Ginetzinsky, A. G., A. J. Broitman \& L. N. Ivanova: Biull. Exp. Biol. i Med. 1954, 38, 37.

Ginetzinsky, A. G. \& L. N. Ivanova: Doklady Akad. Nauk SSSR 1958, $119,1043$. 
Ginetzinsky, A. G., M. G. Sax \& L. K. Titova: Doklady Akad. Nauk SSSR 1958, 120, 216.

Gouge, H. E., A. L. Shor \& W. P. Johnson: Vet. Med. 1959, 54, 342.

Greig, M. E. \& A. J. Gibbons: Science 1956, 123, 939.

Hess, R.: in Diuresis and Diuretics, Ciba Symposium, Berlin 1959, pag. 121.

Ivanova, L. N.: Biull. Exp. Biol. i Med. 1958, 45, 22 (Transl. p. 285) .

Kattus, A., B. Sinclair-Smith, J. Genest \& E. V. Newman: Abstr. Amer. Soc. Clin. Invest. Atlantic City, May 1948.

Kattus, A., B. Sinclair-Smith, J. Genest \& E. V. Newman: Bull. Johns Hopkins Hosp. 1949, 84, 344.

Knudsen, P. J.: Paper presented at the 4th Scandinavian Kidney Session, Helsingfors 1959.

Larvor, P. \& M. Brochart: Ann. de l'Inst. nat. Rech. agron. 1959, 8, 57.

Levinsky, N. G. \& R. W. Berliner: Amer. J. Physiol. 1959, 196, 549.

McSherry, B. J. \& J. Grinyer: Amer. J. Vet. Res. 1954, 15, 609.

Pitts, R. F., F. Krück, R. Lozano, D. W. Taylor, O. P. A. Teidenreich \& R. H. Kessler: J. Pharmacol. \& Exper. Therap. 1958, 123, 89.

Poulsen, E.: Renale Clearranceundersøgelser hos Køer (Thesis), Copenhagen 1956.

Poulsen, E.: Royal Veterinary and Agricultural College, Yearbook, Copenhagen 1957, pag. 97.

Schales, O. \& S. S. Schales: J. Biol. Chem. 1941, 140, 879.

Sellers, A. F., W. R. Pritchard, A. F. Weber \& J. H. Sautter: Amer. J. Vet. Res. 1958, 19, 580.

Sellers, A. F. \& M. H. Roepke: Amer. J. Vet. Res. 1951a, 12, 183.

Sellers, A. F. \& M. H. Roepke: Amer. J. Vet. Res. 1951b, 12, 292.

Shannon, J. A.: Amer. J. Physiol. 1936, 117, 206.

Smith, H. W.: Bull. New York Acad. Med. 1959, 35, 293.

Smith, H. W.: Principles of Renal Physiology, N.Y. 1956, Footnote pag. 91.

Thomsen, A.: Kreatinuri ('Thesis), Copenhagen 1938.

Vander, A. J., R. L. Malvin, W. S. Wilde \& L. P. Sullivan: Amer. J. Physiol. 1958, 195, 558.

Vander, A. J., R. L. Malvin, W. S. Wilde \& L. P. Sullivan: J. Pharmacol. \& Exper. Therap. 1959, 125, 19.

Vogel, G.: Pflügers Arch. 1959, 269, 339.

Wilson, H. Ellis C.: Biochem. J. 1948, 43, 31.

\section{SUMMARY}

Electrolyte Excretion in the Cow, as Influenced by Variations in the Urine Flow.

In a series of cows the following mean values were found for the electrolyte clearances, calculated per $100 \mathrm{~kg}$ body weight:

potassium $110 \mathrm{ml} / \mathrm{min}$. (50-179), percentage excreted $75 \quad(60-98)$

sodium $2 \mathrm{ml} / \mathrm{min}$. $(0.3-6.6), \quad-\quad-1.5(0.2-3.7)$

chloride $1 \mathrm{ml} / \mathrm{min}$. $(0.2-3.9), \quad-\quad \quad-0.8(0.2-2.5)$ 
All three clearances showed a greatly falling tendency during the experimental periods. No correlation was seen between the urine volume and the electrolyte clearances. The plasma potassium level was $3.9 \pm 0.3 \mathrm{mEq} / 1$ and showed great fluctuations during the individual experiment, whereas the plasma levels of sodium $(139 \pm 4)$ and chloride $(102 \pm 4)$ were very stable.

Experiments with chlorthiazide showed that large doses caused a moderate increase of the potassium excretion and a fall of the plasma potassium level, resulting in percentages of excretion exceeding 100 . The sodium and cloride excretions rose considerably parallel with the diuresis. Small doses of chlorthiazide did not influence the potassium excretion, but effected a fall in the plasma potassium level and consequently a slight rise of the percentage excreted. The effects on sodium and cloride were the same in principle as after large doses.

Mersalyl greatly raised the excretions of sodium and chloride parallel with the diuresis. Potassium remained uninfluenced. Two cases occurred of acute mercury poisoning.

\section{ZUSAMMENFASSUNG}

Die Elektrolytausscheidung bei der Kuh unter Diuresevariationen.

Die Untersuchung von Kühen ergab folgende Durchschnittswerte für die Elektrolytausscheidung, auf $100 \mathrm{Kg}$ Lebendgewicht berechnet:

$\begin{array}{lrlcccc}\text { Kalium } & 110 \mathrm{ml} / \mathrm{Min} . & (50-179), & \text { Exkretionsprozent } & 75 & (60-98) \text {, } \\ \text { Natrium } & 2 \mathrm{ml} / \text { Min. } & (0.3-6.6), & - & - & 1.5 & (0.2-3.7) \text {, } \\ \text { Chlorid } & 1 \mathrm{ml} / \text { Min. } & (0.2-3.9), & - & - & 0.8 & (0.2-2.5) \text {. }\end{array}$

Alle drei Ausscheidungen zeigten stark fallende Tendenz während der Versuche. Zwischen der Grösse der Diurese und den Elektrolytausscheidungen wurde keine Korrelation wahrgenommen. Der Plasmawert für Kalium betrug $3.9 \pm 0.3 \mathrm{mEq} / 1$ und zeigte während des einzelnen Versuchs starke Fluktuation, während der Plasmawert für Natrium $(139 \pm 4)$ und für Chlorid $(102 \pm 4)$ sehr stabil war.

Versuche mit Chlorthiazid zeigten, dass grosse Dosen eine mässige Steigerung der Kaliumexkretion und einen Abfall des Plasma-Kaliums bedingten, was Exkretionsprozente über 100 ergaben. Die Natrium- und Chloridausscheidung stieg stark gleichzeitig mit der Diurese. Kleine Dosen von Chlorthiazid beeinflussten die Kaliumexkretion nicht, bewirkten aber einen Abfall der Kaliumkonzentration des Plasmas und damit eine bescheidene Zunahme des Exkretionsprozentes. Die Wirkung auf Natrium und Chlorid war prinzipiell dieselbe wie bei grossen Dosen.

Mersalyl rief in bezug auf Natrium und Chlorid eine kräftige Exkretionssteigerung hervor, die der Diuresezunahme folgte. Kalium wurde nicht beeinflusst. Zwei Fälle von akuter Quecksilbervergiftung kamen vor. 


\section{RESUME}

Elektrolytudskillelsen hos ko under diuresevariationer.

Ved undersøgelser på ko fandtes følgende gennemsnitsværdier for elektrolytclearances beregnet per $100 \mathrm{~kg}$ legemsvægt:

$\begin{array}{lrccrc}\text { Kalium } & 110 \mathrm{ml} / \mathrm{min} & (50-179), & \text { ekskretionsprocent } & 75 & (60-98) \\ \text { Natrium } & 2 \mathrm{ml} / \mathrm{min} & (0.3-6.6), & - & 1.5 & (0.2-3.7) \\ \text { Klorid } & 1 \mathrm{ml} / \mathrm{min} & (0.2-3.9), & - & 0.8 & (0.2-2.5)\end{array}$

Alle tre clearances viste stærkt faldende tendens under forsøgene. Der sås ingen korrelation mellem diuresens størrelse og elektrolytclearances. Plasmaværdien for kalium var $3.9 \pm 0.3 \mathrm{mEq} / \mathrm{l}$ og viste stærk fluktuation under det enkelte forsøg, mens plasmaværdien for natrium $(139 \pm 4)$ og for klorid $(102 \pm 4)$ lå meget stabilt.

Forsøg med chlorthiazid viste, at store doser gav en moderat forøgelse af kaliumexkretionen og fald af plasma-kalium, resulterende $i$ exkretionsprocenter over 100. Natrium- og kloridudskillelsen steg stærkt i takt med diuresen. Små doser chlorthiazid påvirkede ikke kaliumexkretionen, men fremkaldte et fald i plasmaets kaliumkoncentration og dermed en beskeden stigning af exkretionsprocenten. Virkningen på natrium og klorid var principielt som ved store doser.

Mersalyl fremkaldte for natrium og klorids vedkommende en kraftig exkretionsforøgelse, der fulgte diuresestigningen. Kalium påvirkedes ikke. Der forekom to tilfælde af akut kviksølvforgiftning. 